\title{
Individual-Based Factors to Board Culture: Contributions and Detractions
}

\author{
Matt Chilliak*
}

\begin{abstract}
Good governance is integral to facilitating a boardroom culture that contributes to the success of an organization. Individual-based factors to good governance can include individuals' motivations to serve on a board, why they remain on a board, and how they handle conflict within the board. These individual factors contribute to the overall group dynamic of how a board conducts itself and the success of the organization it is in charge of.
\end{abstract}

Keywords: governance, NGOs, politics, culture

\section{Introduction}

The decisions made by an organization's board of directors will be of the utmost importance to the organization. It is at this level that the organization's direction, resource strategy, and raison d'être are determined, as well as where the performance of the chief executive and the organization as a whole is monitored and reviewed. ${ }^{1}$ If the work done by the board is not done well, the entire organization and those who depend on it will suffer. The United Nations

1 Richard T. Ingram, Ten Basic Responsibilities of Nonprofit Boards, 2nd ed. (Washington, DC: BoardSource, 2009), quoted in "What Are the Basic Responsibilities of Nonprofit Boards?", BoardSource, accessed 22 October 2012, http://www.bridgespan.org/getattachment/o7ad15babf1a-48d5-89a3-b5a5db63a515/Basic-ResponsibilitiesNonprofit-Boards.aspx.
Economic and Social Commission for Asia and the Pacific describe governance as "the process of decision-making and the process by which decisions are implemented (or not implemented)." ${ }^{2}$ According to the Institute on Governance, an organization's effectiveness is a result of good governance. ${ }^{3}$ Furthermore, Paul Ledwell explains that "[a] culture of open debate, transparent sharing and grappling with the real issues, and responsibility to help develop strategy is absolutely essential to good governance" and

*Department of Political Studies, College of Arts and Science, University of Saskatchewan, Saskatoon, SK, Canada

Correspondence: mmc806@mail.usask.ca

2 "What Is Good Governance?", United Nations Economic and Social Commission for Asia and the Pacific, accessed 22 October 2012, http://www.unescap.org/pdd/prs/ ProjectActivities/Ongoing/gg/governance.asp.

3 "What Is Good Governance?", Inst itute on Governance, accessed 22 October 2012, http://iog.ca/en/about-us/ governance/what-good-governance. 
that it is about "strong leadership, positive relationships, and shared goals." 4 Ideally, any group with the power to govern at any level in any sector (be it public, private, or non-profit) would exhibit the attributes outlined by Ledwell and would consequently achieve good governance, which would result in organizational effectiveness.

However, ideals are not reality and not all power and decision-making (which are central aspects to the concept of governance) are exercised with good governance fundamentals in mind. By relying on the existing research on the topic, this paper will first explore the concept of board culture, including defining what it is, and then show how assumptions regarding a board member's motivations to join the board, reasons to remain on the board, and the response to conflict from within the board, can contribute to, or detract from good governance, and consequently, organizational effectiveness. Board cultures with members who are motivated to join in order to contribute to their community, who are committed based on an emotional attachment, and who respond to conflict in a constructive manner will contribute to good governance, while board cultures with members who are motivated to join in order to receive recognition, who are committed only because they receive benefit, and who respond to conflict contemptuously will detract from good governance.

\section{Boardroom Culture}

In order to assess how board culture can contribute to or detract from good governance practices in an organization, it is important to look at what board culture is. Some of the definitions described in this paper will refer to organizational culture as opposed to board culture. Regardless of this difference in wording, these organizational definitions are still to be considered valid and relevant to board culture, as a board is simply one type of organization.

As Shili Sun states, there is an abundance of definitions for the concept of organizational culture. ${ }^{5}$ Sun

4 Paul Ledwell, "Governance Matters? Governance Trends for Associations. Speech by Paul Ledwell, President, Inst itute On Governance to Ottawa-Gatineau Chapter, CSAE," Institute on Governance, 26 November 2008, http://iog.ca/wp-

content/uploads/2012/12/2008_November_csae_speech .pdf, 2.

5 Shili Sun, "Organizational Culture and its Themes," International Journal of Business and Management 3, no. notes that Olive Lundy and Alan Cowling's definition of "the way we do things around here" is the most commonly recognized. ${ }^{6}$ While Lundy and Cowling's definition may be easy to comprehend, it is too rudimentary in that it does not give any insight as to what the organization's "way" may be composed of, what the "things" being done are, as well as who and where are referred to as "we" and "here." With more detail, E.H. Schein describes culture itself as "a pattern of basic assumptions, invented, discovered, or developed by a given group, as it learns to cope with its problems of external adaptation and internal integration, that has worked well enough to be considered valid and, therefore is to be taught to new members as the correct way to perceive, think, and feel in relation to those problems." "7 Schein's definition allows us to understand that the "way" Lundy and Cowling referred to are patterns of basic assumptions adapted by a group to deal with the external and internal problems that the group faces; these are the "things." The "we" are the members of the group, and the "here" is the space/place in which the given group operates. ${ }^{8}$ Another detailed definition is given by Nancy R. Axelrod, who explains that "[b]oard culture reflects the human side of association governance: the written and unwritten rules that influence how the board operates, the chemistry between board members and professional staff, and the basic assumptions that individuals bring to their work." ${ }^{\prime 9}$ Common to both Axelrod's and Schein's definitions of board/organizational culture is the concept of basic assumptions that are held by the members of the group. Lastly, Stanley G. Harris provides a more individual-based understanding of organizational culture in his proposal that "the individual-level manifestations and experience of organizational culture are revealed in the operation of a patterned system of organization-specific schemas held by

12 (2008): 137, accessed 22 October 2012, http://www.ccsenet.org/journal/index.php/ijbm/article/v iewFile/760/726.

6 Olive Lundy and Alan Cowling, Strategic Human Resource Management, (London: Routledge, 1996), quoted in Sun, "Organizational Culture and its Themes," 137.

7 E.H. Schein, "Organizational Culture," American Psychologist 45, no. 2 (February 1990): 111.

8 Schein, "Organizational Culture," 111.

9 Nancy R. Axelrod, "In the Boardroom, Culture Counts," Journal of Association Leadership (Fall 2004), http://www.asaecenter.org/

Resources/JALArticleDetail.cfm?ItemNumber $=16167$. 
organizational members," and that this happens within a social context allowing for an interplay between the individual's "sensemaking" and the cultural reality of the group as a whole. ${ }^{10}$ Axelrod and Schein include an individualistic aspect to their group-based definitions of board/organizational culture; conversely, Harris includes an aspect of group dynamics to his individual-based definition. It is clear that both the individual and the group will influence each other in significant ways and, consequently, the culture of the board as a whole.

The basic assumptions of the individuals who serve on a board can manifest themselves as a result of each board member's personal and professional life experiences. This paper will focus on three basic assumptions held by individual board members and how they influence the culture of the board: motivations for joining the board, commitment to continue to serve on the board, and acceptance of dissent within the board. Schein notes that "cultural assumptions reflect the total group's experience, not only the leader's initial assumptions" but that this should not discount the strong effects that a powerful leader can have on a group or board's culture. ${ }^{11}$ This paper does not deny the importance of group dynamics in the construction of the basic assumptions that influence boardroom culture; however, this will not be explored. As this paper will explore the seemingly individual-based basic assumptions of board members (motivation to join, reason to stay, acceptance of dissent and response to conflict), it is important to keep in mind that these basic assumptions did not manifest themselves independently from group dynamics. The basic assumptions of board members can create a certain culture in the boardroom that can be either conducive or disadvantageous to good governance.

\section{Motivation}

The first basic assumption which will be explored is the individual's motivation to join a board. The motivation for joining an organization's board will likely vary based on an individual's pre-existing ideas, experiences, values, and desires. Concerning desires, Sue Inglis notes that "[t]he needs of the board members and the degree board membership is fulfilling to the participant are highly relevant when considering the possibilities of improving

10 Stanley G. Harris, "Organizational Culture and Individual Sensemaking: A Schema Based Perspective," Organizational Science 5, no. 3 (1994): 310. 11 Schein, "Organizational Culture," 115. management and leadership in non-profit organizations." 12 The effect that a board member's needs (or motivations) can have on leadership and management is important in relation to a group's governance, and Ledwell notes that strong leadership and management are essential notions to the successful implementation of good-governance. ${ }^{13}$

Before making a quick conclusion that the organization should meet any of the board members' needs to improve leadership and management on behalf of attaining good governance, these needs must be looked at more closely. Alison J. Doherty and Albert V. Carron touch on some of the needs that motivate board members to join; these include contributing to their community, building social relations for personal and professional reasons, and the recognition that their contribution is important. Doherty and Carron, however, do also note that this grouping of motivations leaves out less desirable responses such as a craving for power. ${ }^{14}$ The assumption that everyone on a board is motivated by reasons that are not self-serving contributes to a culture that is unselfish in achieving its ends. Being motivated by a wish to contribute builds good governance, while being motivated by a desire for recognition detracts from it (that is, unless the entire indicated mission of the group is solely to achieve recognition, which is fairly unrealistic). This is not to say that an individual on a board may not possess some mixture of these motivations or that any such mixture would completely detract from good governance; instead, if it is to work towards good governance, the overwhelming motivation should be to contribute. This good governance is encouraged when a board's culture is shared, in that it is an unselfish contribution to one's community that is the driving (not necessarily sole) motivation for the members who join a board, instead of an egocentric motivation for the enjoyment of recognition.

12 Sue Inglis, "Exploring Volunteer Board Member and Executive Director Needs: Importance and Fulfillment," Journal of Applied Recreation Research 19, no. 3: 172, http://www.sirc.ca/newsletters/mayog/documents/3933 40.pdf.

13 Ledwell, "Governance Matters? Governance Trends for Associations," 2.

14 Alison J. Doherty and Albert V. Carron, "Cohesion in Volunteer Sport Execut ive Committees," Journal of Sport Management 17 (2003): 117, http://journals.humankinetics.com/AcuCustom/SiteNa me/Documents/ Documentltem/579.pdf. 


\section{Commitment}

The basic assumption of an individual's motivation to join a board is followed by basic assumptions of why that individual continues to remain with the board over time or, in other words, his or her commitment to the board. Meyer and Allen list three components of commitment: affective, which focuses on an individual's emotional attachment to a group; normative, which focuses on an individual's feeling of moral duty to a group; and continuative, which focuses on an individual's need to remain within a group in order to avoid costs associated with leaving. ${ }^{15}$ Preston and Brown find that affective commitment is a driving force for a board's performance. ${ }^{16}$ Interestingly, Preston and Brown also find that board performance is not negatively affected when an individual is committed for reasons of personal benefit; ${ }^{17}$ however, self-interested commitment will detract from good governance in that it does not contribute to the assumption that all members are working toward the same goal. The basic assumption of an individual's commitment to an organization is essential in that, according to Ledwell's definition, "shared goals" are a defining aspect to good governance. ${ }^{18}$

Just as a board member's motivations to join may be constituted by multiple types of the member's needs, so the commitment to remain on a board may include all the different components of commitment listed above. That is, an individual's commitment may be constructed from emotional attachment, moral duty, and self-interested benefits. As with what motivates individuals to join a board, the predominant factor of an individual's commitment is most important in regards to good governance. When a board's members are all assumed to be committed primarily because of an emotional attachment, good governance is encouraged. If a board's members are not primarily committed by emotional attachment to an organization for the ends of that organization but are

15 J. Meyer and N. Allen, Commitment in the Workplace: Theory, Research, and Application, (Thousand Oaks, Calif.: Sage, 1997) quoted in Jennifer Bright Preston and William A. Brown, "Commitment and Performance of Nonprofit Board Members," Nonprofit Management and Leadership 15, no. 2 (2004): 225, doi:10.1002/nml.63.

16 Preston and Brown, "Commitment and Performance of Nonprofit Board Members," 233.

17 Ibid., 234.

18 Ledwell. "Governance Matters? Governance Trends for Associations," 2. instead committed for reasons of obligation or personal self-interest, then good governance will be hard to come by in that organization.

\section{Conflict Response}

The importance Ledwell attributes to open debate for good governance ${ }^{19}$ argues for a close look at board members' basic assumptions and, consequently, how dissent and conflict are dealt with in board culture. This touches on what Schein referred to as "internal integration," 20 and what Axelrod referred to as "chemistry between board members." 21 The manner in which the individuals on a board respond to dissent within the group is highly important, as argument and discussion are integral aspects of group decision-making. The culture of a board will suffer when it responds negatively to criticism and conflict from within, as Axelrod points out:

A healthy culture is not present when CEOs and managers do not make it safe for their staff members and their board members to question inconsistencies, perceived improprieties, or dubious practices. It is not present when board members do not question peers who put their own interests above the interests of the entire organization or become external critics before they have shared their concerns through proper, internal channels. It is not present when board members who express intelligent doubt in a responsible manner are ignored, labeled as disruptive, or even urged to end their board service. ${ }^{22}$

This type of unhealthy behavioural response to dissent within the board's culture will most definitely detract from the open debate that is necessary for good governance.

Axelrod notes that effective boards will value cohesion and inclusion within a group and will promote better decision-making than individuals alone, but that there is also a risk of falling into "group-think" decision-making patterns. ${ }^{23}$ Therefore, caution should be exercised when there appears to be no conflict or dissent at all among a board's members. Instead of immediately declaring that success is achieved in a board's unanimous approval of a

19 Ibid., 6.

20 Schein, "Organizational Culture," 111.

21 Axelrod, "In the Boardroom, Culture Counts."

22 Ibid.

23 Ibid.

University of Saskatchewan Undergraduate Research Journal 
decision, the possibility needs to be considered as to whether it could be that board members have fallen into a pattern of group-think decision-making where conflict and dissent are non-existent. Good governance is not present merely when there is no conflict or dissent within the board; rather, it is present when the conflict and dissent within the board are dealt with in an objective, welcoming, and orderly manner.

\section{Conclusion}

In order to contribute to good governance, an organization's board should exhibit a culture made of the following basic assumptions: members are motivated to join in order to contribute to their community; they continue to serve on the board out of an emotional attachment to the organization, and conflicting opinions are encouraged to be openly discussed. An organization's board may detract from good governance when it exhibits the following basic assumptions: members are motivated to join primarily to receive recognition; they continue to serve because the personal costs of leaving are too high, and conflicting opinions are discouraged by punishment of those who dissent. It may be difficult to pinpoint a board that includes cultural aspects that adhere strictly to either contributing to or detracting from good governance. Instead of looking at good governance in a categorical approach where a board's culture either contributes to or detracts from good governance, it might be more useful to think of good governance as a spectrum on which an organization can fall somewhere in between the two poles of contributing and detracting. The organization's board's position on the spectrum is never fixed and is always moving with the changing culture of the organization and its board's members.

The United Nations Economic and Social Commission for Asia and the Pacific claims that good governance is consensus orientated, participatory, law abiding, effective and efficient, accountable, transparent, equitable and inclusive, and responsive. ${ }^{24}$ Whether in a boardroom or any other type of organizational leadership environment in the public, private, or non-profit sectors, the culture that permeates at the top, where the decision-making power is located, will have an important effect on the rest of the organization. Board cultures are influenced by the individuals who constitute the board, as well as the group dynamics which result from the interaction of each individual's personal and professional life experiences and basic assumptions. To return to the Institute of Governance's endorsement of good governance as leading to organizational effectiveness, ${ }^{25}$ it should be noted that any organization that wishes to achieve its goals should promote individuals to the board who will adhere to the mentality of good governance principles. Board cultures that promote good governance practices will benefit the organization as a whole, while board cultures that detract from good governance will dampen the ability of the organization to achieve its goals.

\section{Reference List}

Axelrod, Nancy R. "In the Boardroom, Culture Counts." Journal of Association Leadership. (Fall 2004). http://www.asaecenter.org/Resources/JALArticleDetail.cf m?ItemNumber $=16167$.

Doherty, Alison J. and Albert V. Carron. "Cohesion in Volunteer Sport Executive Committees." Journal of Sport Management. 17 (2003): 116-141.

http://journals.humankinetics.com/AcuCustom/SiteName / Documents/Documentltem/579.pdf.

Harris, Stanley G. "Organizational Culture and Individual Sensemaking: A Schema Based Perspective." Organizational Science 5, no. 3 (1994): 309-321.

Inglis, Sue. "Exploring Volunteer Board Member and Executive Director Needs: Importance and Fulfilment." Journal of Applied Recreation Research 19, no. 3 (1994): 171-189. http://www.sirc.ca/newsletters/mayog/documents/39334 o.pdf.

Ledwell, Paul. "Governance Matters? Governance Trends for Associations. Speech by Paul Ledwell, President, Institute On Governance to Ottawa-Gatineau Chapter, CSAE," Institute on Governance. Accessed 22 October 2012. http://iog.ca/wpcontent/uploads/2012/12/2008_November_csae_speech. pdf.

Preston, Jennifer Bright and William A. Brown. "Commitment and Performance of Nonprofit Board Members." Nonprofit Management and Leadership 15, no. 2 (2004): 221-238. doi:10.1002/nml.63.

Schein, E.H. "Organizational Culture." American Psychologist 45, no. 2 (February 1990): 109-119. 
Shili, Sun. "Organizational Culture and its Themes." International Journal of Business and Management 3, no. 12 (2008): 137-141. Accessed 22 October 2012.

http://www.ccsenet.org/journal/index.php/ijbm/article/vie wFile/76o/726.

"What Are the Basic Responsibilities of Nonprofit Boards?" BoardSource. Accessed 22 October 2012.

http://www.bridgespan.org/getattachment/o7ad15babf1a-48d5-89a3-b5a5db63a515/Basic-ResponsibilitiesNonprofit-Boards.aspx.

"What Is Good Governance?" Institute on Governance. Accessed 22 October 2012. http://iog.ca/en/about-us/governance/what-good governance.

"What Is Good Governance?" United Nations Economic and Social Commission for Asia and the Pacific. Accessed 22 October 2012.

http://www.unescap.org/pdd/prs/ProjectActivities/Ongoi ng/gg/governance.asp. 